Journal of Nepal Geological Society, 2019, vol. 59, pp. 65-72

DOI: https://doi.org/103126/jngs.v59i0.24989

\title{
Assessment on connection between shallow and deep aquifers of Siraha and Saptari Districts using isotope analysis
}

\author{
*Rabina Hada1, Maarten Lupker², Ananta Prasad Gajurel', and Nir Shakya1 \\ ${ }^{\prime}$ Department of Geology, Tri-Chandra Multiple Campus, Tribhuvan University, Kathmandu, Nepal \\ ${ }^{2}$ ETH-Zurich, Switzerland Department of Earth Sciences \\ *Corresponding author: hadarabina2@gmail.com
}

\begin{abstract}
Total 26 samples, 6 from river, 7 from deep tube well and 13 from shallow tube wells were analysed for the isotopic composition and chemical composition of the water at different sources. The main focus of the study was to assess connection between aquifers, and recharge zone analysis of the local groundwater system in the Siraha and the Saptari Districts, west of the Koshi River. The $\delta^{18} \mathrm{O}$ composition of the Koshi River was found to be the lightest whereas the shallow tube wells at Haripur and Shambhunath were the heaviest. The $\delta^{18} \mathrm{O}$ composition at many locations showed identical values showing the correlation of water within the aquifers and also with the surface water. Based on the plot of $\delta^{18} \mathrm{O}$ vs $\delta^{2} \mathrm{H}$, the shallow tube well at Asanpur and the deep tube well at Jamdaha were suspected to be recharged from the Kharak Khola. Similarly, the deep tube wells at Lalpur and Kusaha, the shallow tubes well at Asanpur, Tudkiya and Raghunathpur, and the Mahuli Khola and the Khado Khola are interconnected. The deep tube wells at Tudkiya, Dhangadhi and Phulkakatti might have interconnection with the shallow tube wells at Khoriya and Golamukhsar.
\end{abstract}

Keywords: Groundwater connectivity, Environmental isotopes, Siraha District, Shallow tube well, Deep tube well

Paper Received: 3 Apr 2019

Paper Accepted: 5 Jun 2019

\section{INTRODUCTION}

Groundwater flows through the pore spaces from higher elevation to lower elevation (Pinder, 2006). Water from precipitation adds to the system and then typically leaves the groundwater system into nearby surface water body, occupying the area of lower elevation or through evapotranspiration during the growing season (USGS, 2018). The Terai relies greatly on the groundwater for the industrial and agricultural purpose. Groundwater is the main source of water used for the purpose of drinking and irrigation in the Terai region of Nepal. Besides, it has been an important source in the development of the industries as well as hospitals. The Koshi River is the main water body that drains all the flowing water from eastern Nepal to India and likely to recharge groundwater bodies underlying the surface therein.

The natural state, composition and the groundwater flow direction within the aquifer system must be known for its proper use. Isotopes, when used in groundwater hydrology give a direct insight into the movement and distribution processes within aquifers. Groundwater, in its natural state, contains environmental isotopes and conclusions may be drawn from their abundance variation (Terwey, 1984). Isotopes can provide preliminary indication of the flow paths and origins of the water. This information is important to access the groundwater during drilling (Nayak, 2016). Many researches related to groundwater hydrology, and arsenic contamination in Terai, Nepal are known. Kunwor (1993) studied about the aquifer parameters with reference to the prevailing hydrogeological condition at Bheri, Terai area (Banke/Bardiya), mid-Western region, Nepal. Pathak and Rao (1998) investigated about the groundwater recharge to the confined aquifer in the Terai Plain, Nawalparasi District, western Nepal. Pokhrel et al. (2009) studied about the arsenic contamination of groundwater in the Terai region, Nepal. However, the connectivity of the aquifers in the Siraha and the Saptari Districts near the Koshi River area has not been studied since date.

The main aim of the study is to assess connection between the surface and ground water and also to analyse the recharge zone of the shallow and the deep aquifers in the Siraha and the Saptari Districts, eastern Nepal. Such study gives the mapping information that links the surface water and groundwater.

The quality analysis of the water gives the clear insight about the aquifer characteristic. The concentration of the dissolve ions and the physical parameters of the water gives clear view about the types of rock that water has encountered in its flow path and hence assumption can be made about the flow direction. The chemical parameters such as ion concentration, provides the supportive endorsement for the clear insight of the connectivity within the aquifers and surface water. Stable isotopic approach is being used to study the groundwater interaction within the aquifers (deep and shallow) and also surface (river) water at the Koshi River area.

\section{STUDY AREA}

The study area lies in some parts of the Saptari and the Siraha Districts of the Eastern Development Region (Fig. 1), Terai, Nepal. The area covers the western part of the Koshi 

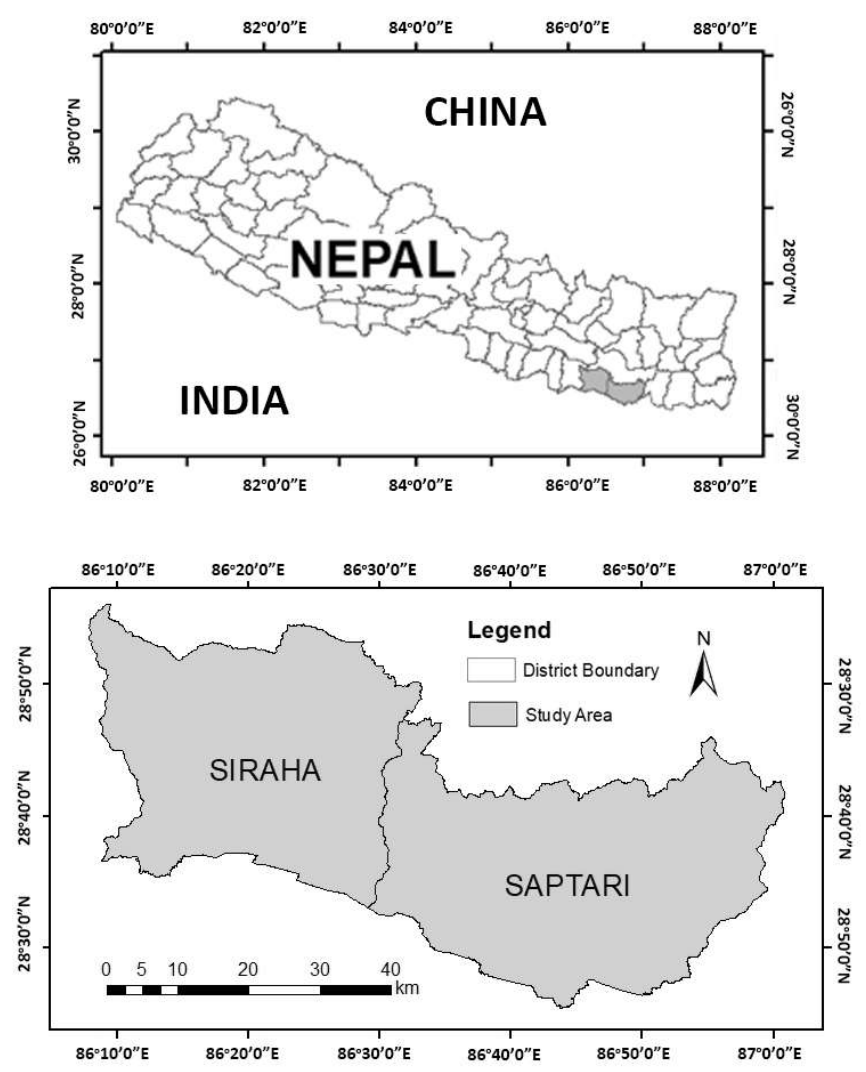

Fig. 1: Location map of study area

River. The Siraha District is occupied by both mountainous regions at north and the Terai region at south. Both Siraha and Saptari Districts have connection with the Indian borders at the southern part. The climate of the study area lies in subtropical region and is warm. The temperature rises up to $40^{\circ} \mathrm{C}$ in the summer.

The eastern part of the Terai receives more rainfall than the western part, and is highly affected by flood during monsoon. The natural vegetation covers are subtropical evergreen forest in the Northern Terai and the Chure Range. The study area consists of mainly three types of river systems; i) large river whose source is the snowmelt from the Himalayas, runoff water and also groundwater; ii) Foothill rivers or rivers from the Siwaliks originating just below at the foot of the mountains and whose source is the groundwater and the surface runoff water and iii) Plain river that originates at the plain of the Terai and the source is local groundwater. The Koshi River is the major large river flowing across the districts from the north to the south and drains towards India. The Gagan Khola is the foothill river that lies near to the Siwaliks. The Balan Khola, Khado Khola, Khadak Khola, and the Mahuli Khola are some of the Plain rivers present in the study area.

The study area lies in the Indo-gangetic Plain and the Lower Siwaliks. Ground water is the major source of water in the Terai region. The Terai is the foreland basin filled with the Pleistocene to Holocene sediments (Dhital, 2015). Since the Terai is filled up by the recent alluvial deposit, it has the potential to hold the groundwater within it and that plays an important role in formation of the aquifer system. Study of Ground water consultants (GRDP, 1994), has shown that an estimated 7, 26,000 ha. of the Terai land can be potentially developed for shallow tube wells. Similarly, 305,000 ha. have marginal potential for shallow tube wells.

\section{METHODOLOGY}

Topographic maps, google imageries, published lithological data and published reports were used for the initial assessment of the study area. The conductivity, $\mathrm{pH}$ and temperature were noted using conductivity meter and $\mathrm{pH}$ meter in field. About 26 samples, 13 samples from shallow tube well, 7 samples from deep tube well and 6 samples from river, were collected for chemical and isotopic analysis in laboratory (Fig. 2). The overall methodology used during the study are presented in the flow chart. (Fig. 3).

The chemical ion concentration of seven parameters i.e. Chloride, Calcium, Magnesium, Total hardness, Total alkalinity, Phosphate and Iron, was identified using titrimetric analysis. Stable isotopic analysis was done in the laboratory of ETH Zurich, Switzerland.

\section{RESULT AND DISCUSSION}

\section{Physical properties of water}

The physical properties of the water such as conductivity, $\mathrm{pH}$, temperature measured in situ in the field are presented. The conductivity value was highest at Sigw13 with the value of 658 $\mu \mathrm{s} / \mathrm{cm}$ at an altitude of $164 \mathrm{~m}$ and lowest at Sigw 19 with the value $101 \mu \mathrm{s} / \mathrm{cm}$ at an altitude of $114 \mathrm{~m}$. The value of conductivity shows connectivity at deep tube well of Sigw4, Sigw11 and shallow tube well at Sigw13. Similarly, the conductivity value shows correlation of shallow tube well at Sigw12, deep tube well at Sigw3 and Sigw22. The conductivity value shows correlation at Sigw24, Sigw25, shallow tube well at Sigw6,

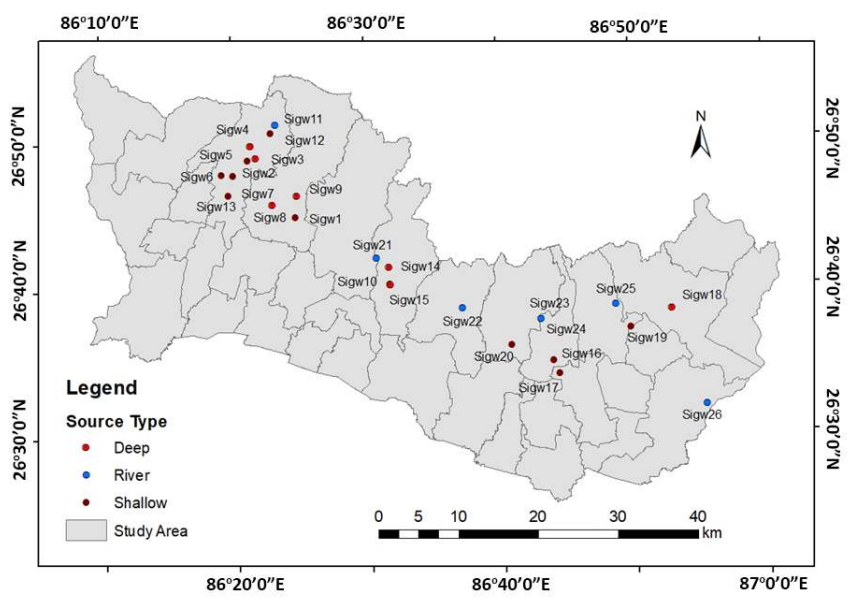

Fig. 2: Location map of study area with samples collected 


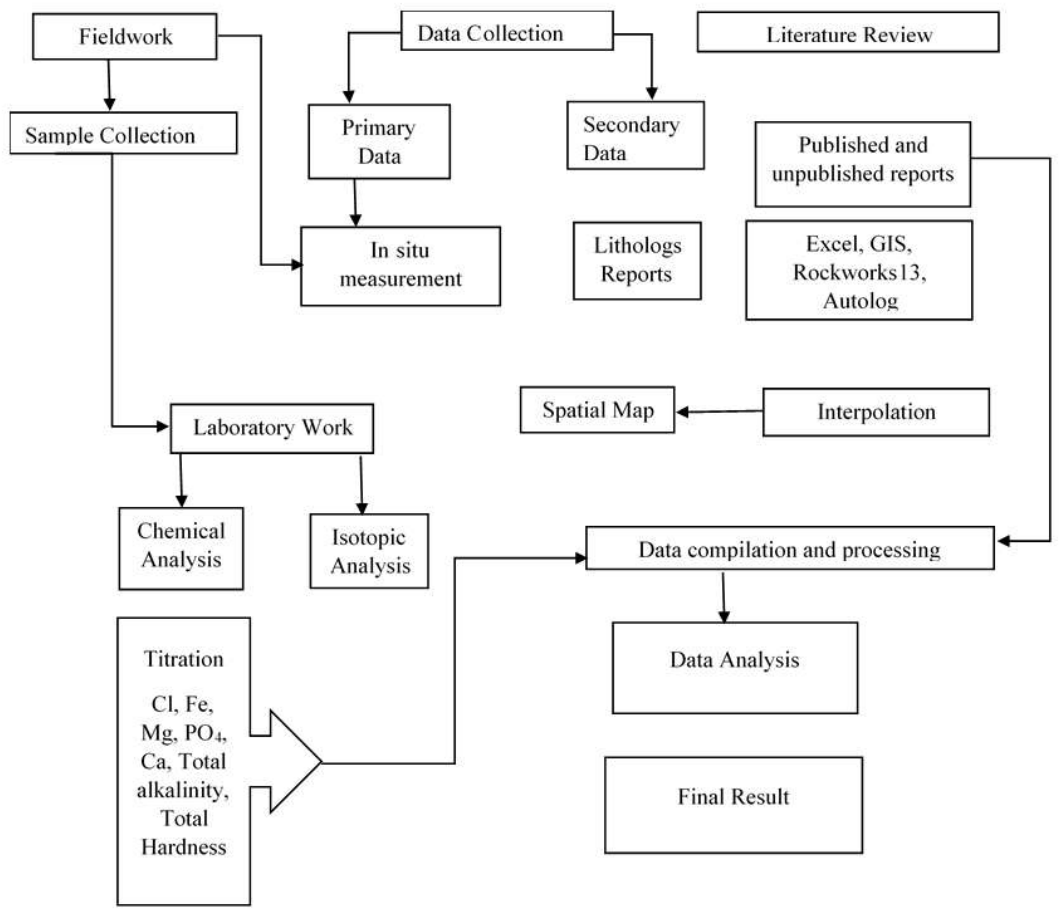

Fig. 3: Flow chart of methodology

Sigw7 and Sigw10 and deep tube well at Sigw2. Similarly, Sigw20 can be correlated with the deep tube well at Sigw18. samples of deep tube well at Sigw14, Sigw21 and shallow tube Shallow tube well at Sigw1, Sigw5, Sigw16 and Sigw19 has well at Sigw23 can be correlated with each other. In the mean the correlative value with the deep tube well at Sigw8, Sigw9, way, the samples of shallow tube well at Sigw15, Sigw17 and and Sigw26.

Table 1 Physical properties of the sample

\begin{tabular}{llcccc}
\hline Sample no. & Location & Altitude $(\mathrm{m})$ & Temperature $\left({ }^{\circ} \mathrm{C}\right)$ & Conductivity $(\mu \mathrm{s} / \mathrm{cm})$ & $\mathrm{pH}$ \\
\hline Sigw1 & Khoriya & 125 & 31.8 & 177 & 5.86 \\
Sigw2 & Tudkiya & 157 & 32.2 & 464 & 6.49 \\
Sigw3 & Lalpur & 163 & 25.6 & 562 & 6.67 \\
Sigw4 & Jamdaha & 172 & 25 & 625 & 6.82 \\
Sigw5 & Asanpur & 116 & 25 & 179.7 & 6.35 \\
Sigw6 & Chaharwa & 126 & 25 & 443 & 6.64 \\
Sigw7 & Nipane & 118 & 25 & 472 & 6.7 \\
Sigw8 & Phulkakatti & 134 & 25 & 143 & 6.13 \\
Sigw9 & Bedartole & 150 & 25 & 175 & 5.9 \\
Sigw10 & Haripur & 71 & 24.8 & 412 & 6.25 \\
Sigw11 & Gagan khola & 206 & 25.6 & 635 & 6.7 \\
Sigw12 & Golamukshar & 196 & 25 & 576 & 7.08 \\
Sigw13 & Tudkiya & 164 & 24.9 & 654 & 6.7 \\
Sigw14 & Kushaha & 116 & 24.9 & 311 & 5.7 \\
Sigw15 & Haripur & 119 & 24.8 & 286 & 5.4 \\
Sigw16 & Basbitty & 94 & 25 & 169 & 5.7 \\
Sigw17 & Maleth & 91 & 25 & 212 & 4.8 \\
Sigw18 & Raghunathpur & 102 & 25 & 208 & 6.33 \\
Sigw19 & Lohazara & 114 & 25.3 & 101 & 4.74 \\
Sigw20 & Shambhunath & 106 & 25 & 215 & 5.65 \\
Sigw21 & Balaan Khola & 120 & 25 & 363 & - \\
Sigw22 & Kharak Khola & 116 & 25 & 549 & - \\
Sigw23 & Rupni & 114 & 24.8 & 356 & - \\
Sigw24 & Khado Khola & 111 & 25 & 480 & - \\
Sigw25 & Mahuli Khola & 119 & 25 & 424 & - \\
Sigw26 & Koshi River & 68 & 25 & 167 & - \\
\hline & & & & &
\end{tabular}




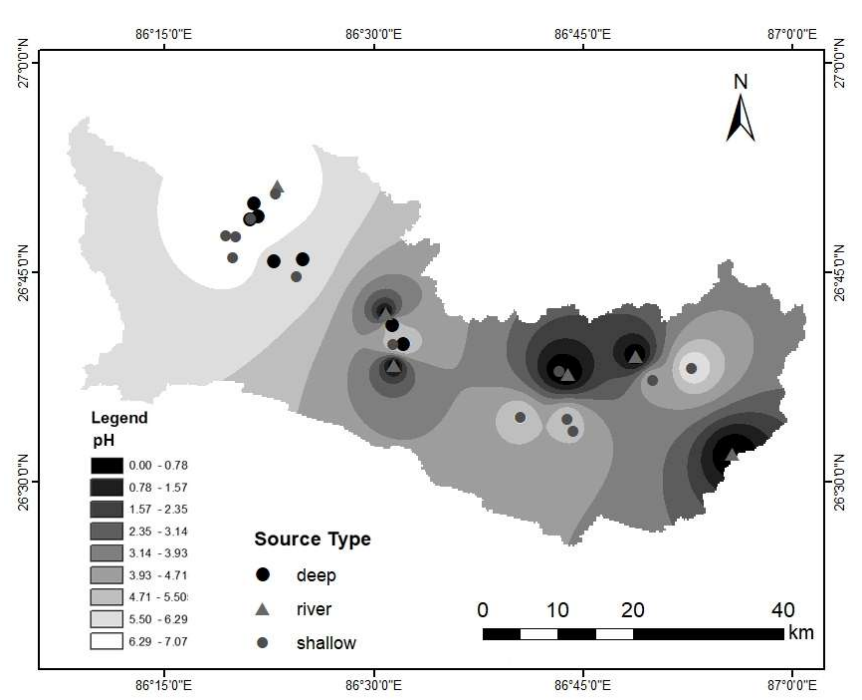

Fig. 4: Spatial distribution of $\mathrm{pH}$

The spatial distribution map of $\mathrm{pH}$ in Fig. 5 shows correlation of the shallow tube well at Sigw6, Sigw7, Sigw12 and Sigw13 with the deep tube well at Sigw3, Sigw2 and Sigw4 and also with the river sample of Sigw11.Similarly, the shallow tube well at Sigw1, Sigw15, Sigw16 and Sigw20 can be correlated with the deep tube well of Sigw8, Sigw9 and Sigw18. Also, the shallow tube well at Sigw15 and Sigw17 can be correlated with deep tube well of Sigw14. The $\mathrm{pH}$ value of the samples from Sigw21 to Sigw26 is shown minimum in the map due to the unavailability of data.

\section{Chemical parameters}

On the basis of chemical parameters, the ion concentration of shallow tube well at Sigw1, Sigw14, Sigw16, Sigw17, Sigw19 and deep tube well at Sigw3, Sigw8, Sigww9, Sigw10, Sigw20, Sigw18 has correlating value with each other (Table 2). Similarly, the value of ion concentration shows correlation of shallow tube well at Sigw6 with deep tube well at Sigw2, Haripur and river water at Sigw11, Sigw21 and Sigw22. In addition to it, the samples at Sigw6, Sigw7, Sigw12 and Sigw13 can be correlated based on the overall ion concentration plotted in Fig. 4. The highest concentration of the chloride, calcium, magnesium, total alkalinity, phosphate and total hardness was found at the Asanpur (Sigw5) and the iron concentration was found comparatively lower than other ions. This result show that the shallow water in Asanpur is contaminated compared to other water samples from different sources. The contamination may be resulted due to the anthropogenic activities near the source area. Fig. 5 shows the overall plot of the chemical ion concentration at different sources.

\section{Isotopic Connectivity}

The $\delta^{18} \mathrm{O}$ composition of the ground water and river water shows correlation between them. The sample from Haripur

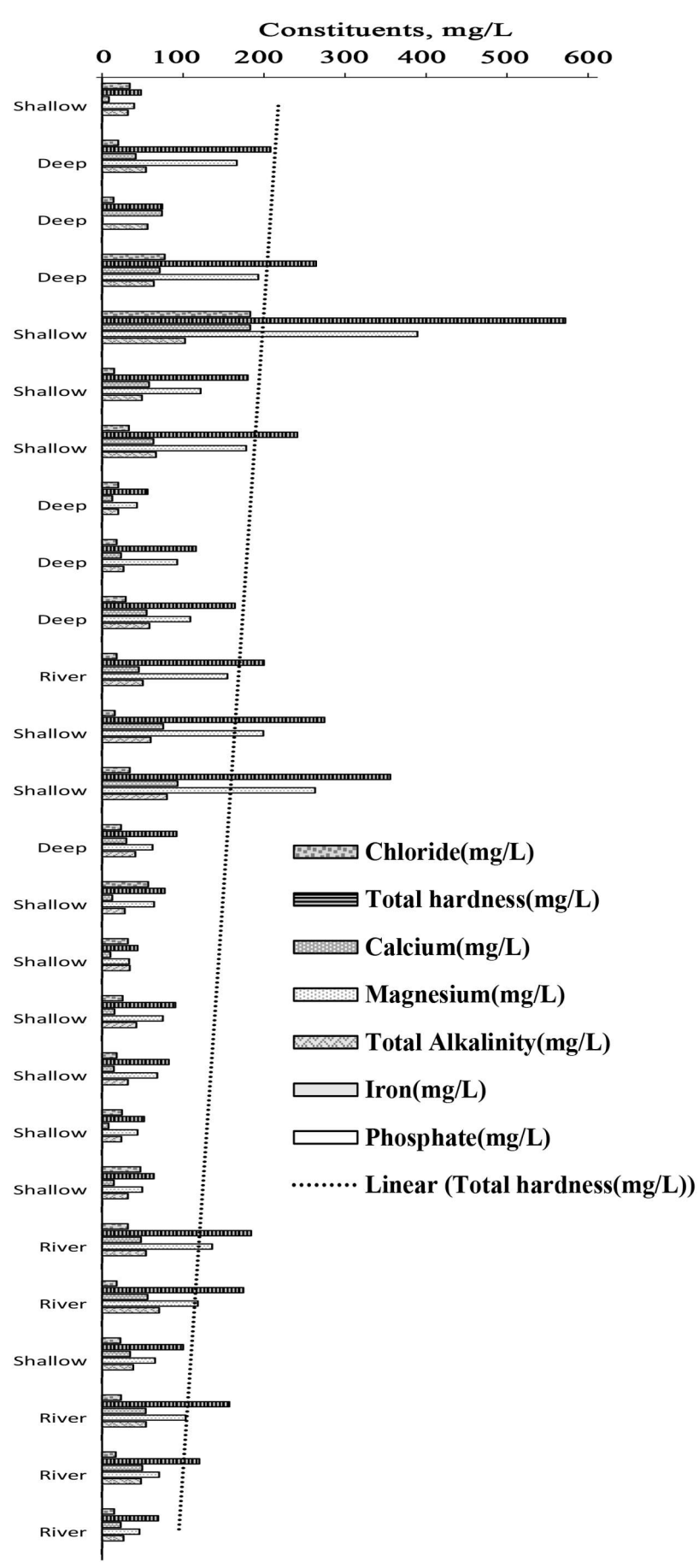

Fig. 5: Overall plot of the ion concentration

(Sigw15) and Sambhunath (Sigw20) has the heaviest isotopic value $(-4.3 \%$ and $-4.8 \%$ ) whereas the water from the Koshi River (Sigw26) has the lightest isotopic value (-10.2\%) (Table 2). The Gagan Khola (Sigw11), the river flowing from the Siwaliks has the $\mathrm{d} 18 \mathrm{O}$ value of $-7.7 \%$.

The river sample at Mahuli Khola (Sigw25) and Khado Khola (Sigw24), the deep tube well at Lalpur (Sigw3) and Kusaha (Sigw14) and also the shallow tube well at Asanpur 


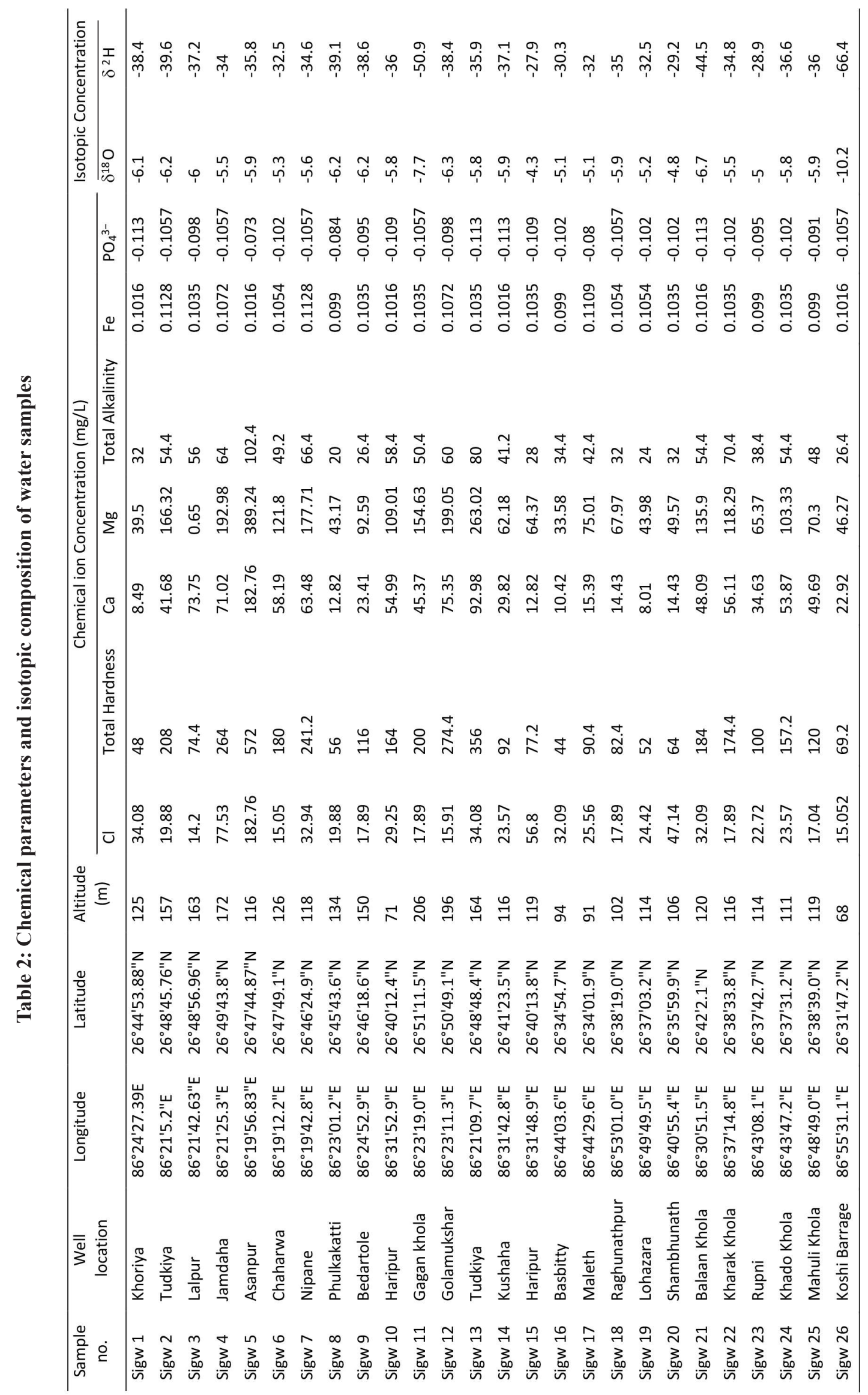




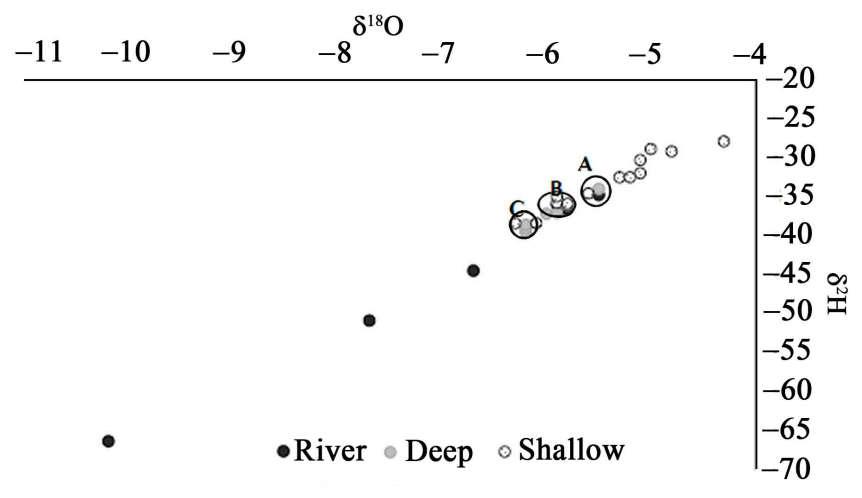

Fig. 6:Plot of $\delta^{18} \mathrm{O}$ vs $\delta^{2} \mathrm{H}$

(Sigw5), Tudkiya (Sigw13) and Raghunathpur (Sigw18) are categorized as Cluster B (Fig. 6). Similarly, the deep tube well at Tudkiya (Sigw2), Dhangadhi (Sigw8), Phulkakatti (Sigw9) and shallow tube well at Khoriya (Sigw1) and Golmukhsar (Sigw12) are clustered around and categorized as Cluster C (Fig. 6). From the figure, in Cluster A, it can be concluded that the shallow tube well at Asanpur (Sigw7) and deep tube well at Jamdaha (Sigw4) might be recharged from the Kharak Khola (Sigw22). Similarly, deep tube well at Lalpur and Kusaha, shallow tube well at Asanpur, Tudkiya and Raghunathpur from Cluster B might be recharged from the Mahuli Khola or the Khado Khola and hence the Mahuli Khola and the Khado Khola might be interconnected. In Cluster C, the deep tube well at Tudkiya, Dhangadhi and Phulkakatti might have interconnection with the shallow tube well at Khoriya and Golamukhsar.

\section{Cross Section}

A-A' section shown in Fig. 7 covers the west-east profile of the study area. It consists of four boreholes BH4, BH6, BH2 and $\mathrm{BH} 3$ representing the sampling points Asanpur, Khoriya (Sigw1), Kusaha(Sigw14) and Shambhunath(Sigw20). From the cross-sectional profile, the western zone has dominance of coarse-grained sediments which is mostly gravel. This suggests there is significant percolation of the water in the ground in this area. In contrast, the gravels have dramatic drop down in the quantity towards the eastern part. While moving along the eastern area, the thickness of the sandy clay and clay increases. This implies the water flow has directed towards east from west with good storage of water in the clay layer. The $\delta^{18} \mathrm{O}$ and $\delta^{2} \mathrm{H}$ of the water samples at borehole BH4 are $-5.9 \%$ and $-37.1 \%$, BH6 are $-6.1 \%$ and $-38.4 \%$, BH2 are $-5.9 \%$ and $-37.1 \%$, and BH3 are $-4.8 \%$ and $-29.2 \%$, respectively. The isotopic composition of the water samples at the three borehole locations (BH4, BH6, BH2) also supports the connectivity within the aquifers. The section shows four confined aquifers consisting sand and five confined aquifers consisting gravel.

The section B-B' in Fig. 8 shows the north-south profile of the study area. It consists of three boreholes namely BH8, $\mathrm{BH} 7$ and $\mathrm{BH} 5$ representing the sampling points Golamukhsar, Lalpur and Phulkakatti, respectively. The northern part of the section consists of sand, gravel and sandy clay in equal proportion whereas in the southern part of the section, there is the dominance of gravel. In general, the proportion of coarser material (gravel) must be greater at the northern part and gradually decreases towards south. However, in this section the proportion of gravel is uniform throughout the section. This suggests, there is good storage of groundwater in the gravel and sand layers in the southern part. The $\delta^{18} \mathrm{O}$ and $\delta^{2} \mathrm{H}$ of water samples at the borehole BH 8 are $-6.3 \%$ and -38.4 , BH7 re $-6 \%$ and $-37.2 \%$ and BH5 re $-6.2 \%$ and $-39.1 \%$, respectively. The isotopic composition of the water samples at the three borehole locations (BH8, BH7, BH5) also shows the connectivity within the tube wells. The section shows three confined aquifers and one unconfined aquifer consisting gravel at the southern part and one confined aquifer consisting sand that spreads throughout the section.

\section{3-D correlation of subsurface logged data}

Selecting 9 lithological logs distributed in different directions, correlation of lithology was made (Fig. 9). The northern part consists dominantly of coarser sediments (gravel).

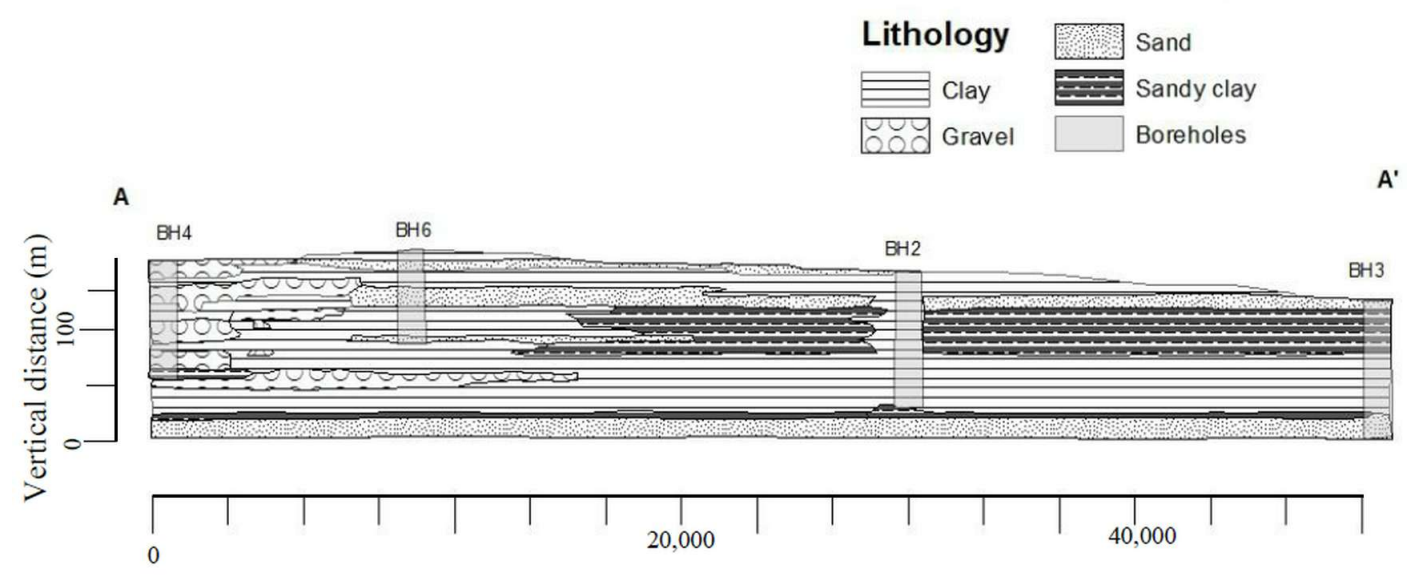

Fig. 7: Cross section profile A-A'

Horizontal distance (m) 


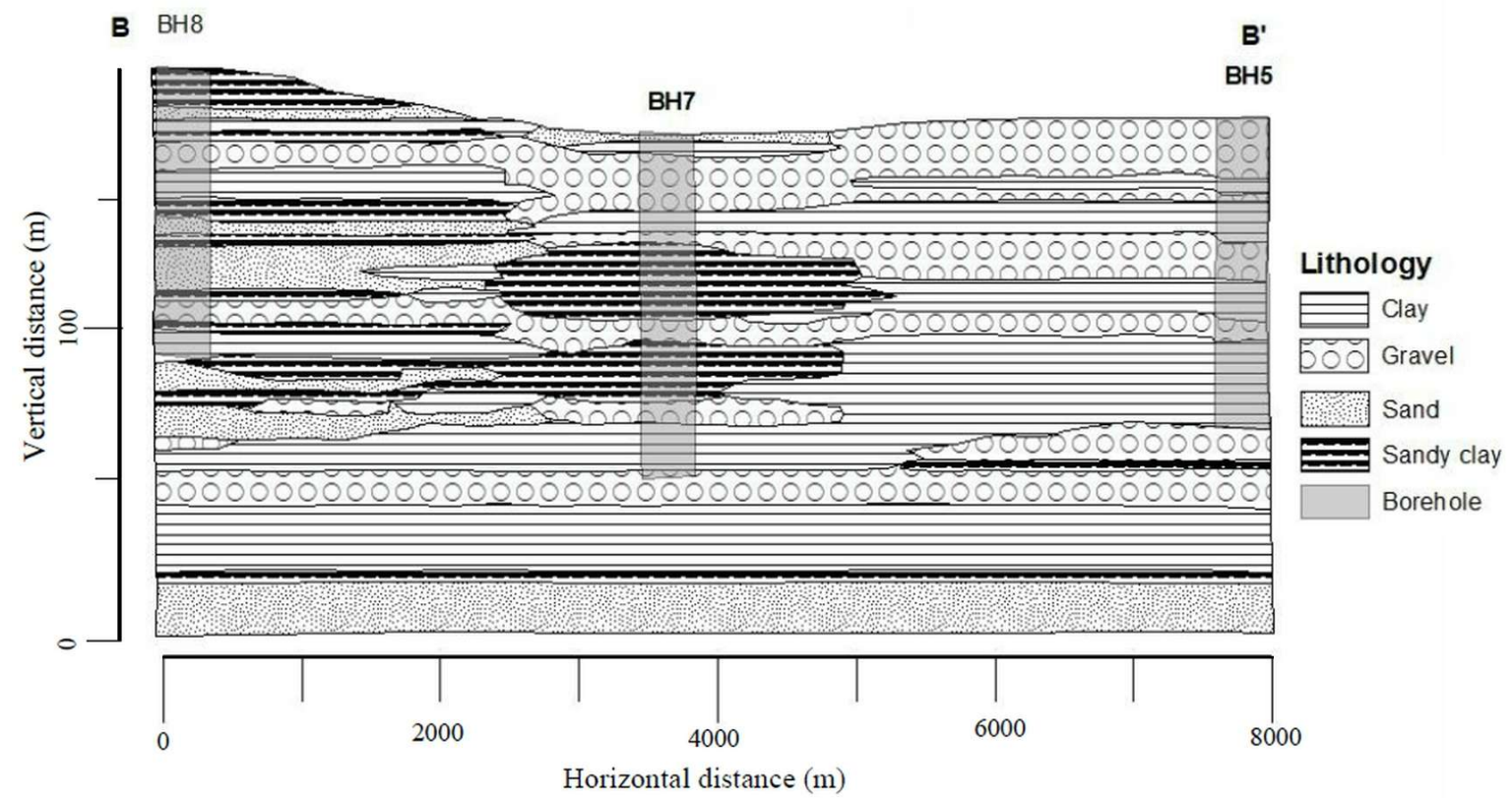

Fig. 8 Cross section profile B-B'

Whereas on moving southwards, the proportion of coarse material decreases gradually and the fine sediments (Clay and Sandy Clay) increases in proportion. The dominance of coarse material towards northern part advocates high groundwater recharge potential at north and abundance of finer sedimentary sequence towards south indicates higher groundwater storage potential. The greater proportion of gravel layer towards western and northern part supports the higher potential for shallow aquifer system. Whereas towards southern and eastern part, good potential for the deep aquifer system can be noted.

\section{CONCLUSION}

The physical parameters, conductivity and $\mathrm{pH}$ value show correlation within the groundwater aquifers and the surface water. The identical chemical ion concentration suggests the connectivity within the shallow and deep aquifers and river

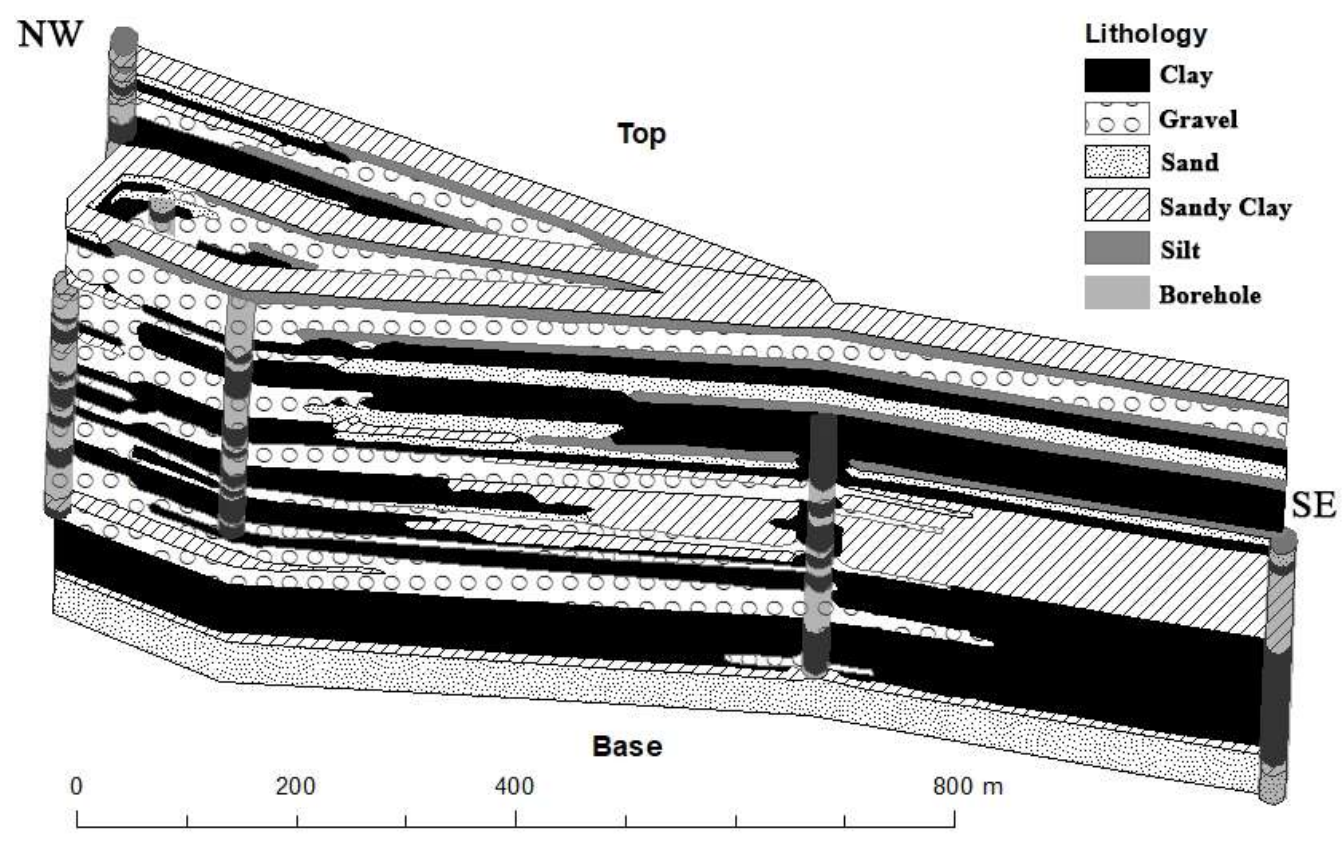

Fig. 9: Correlation of subsurface lithologic logs 


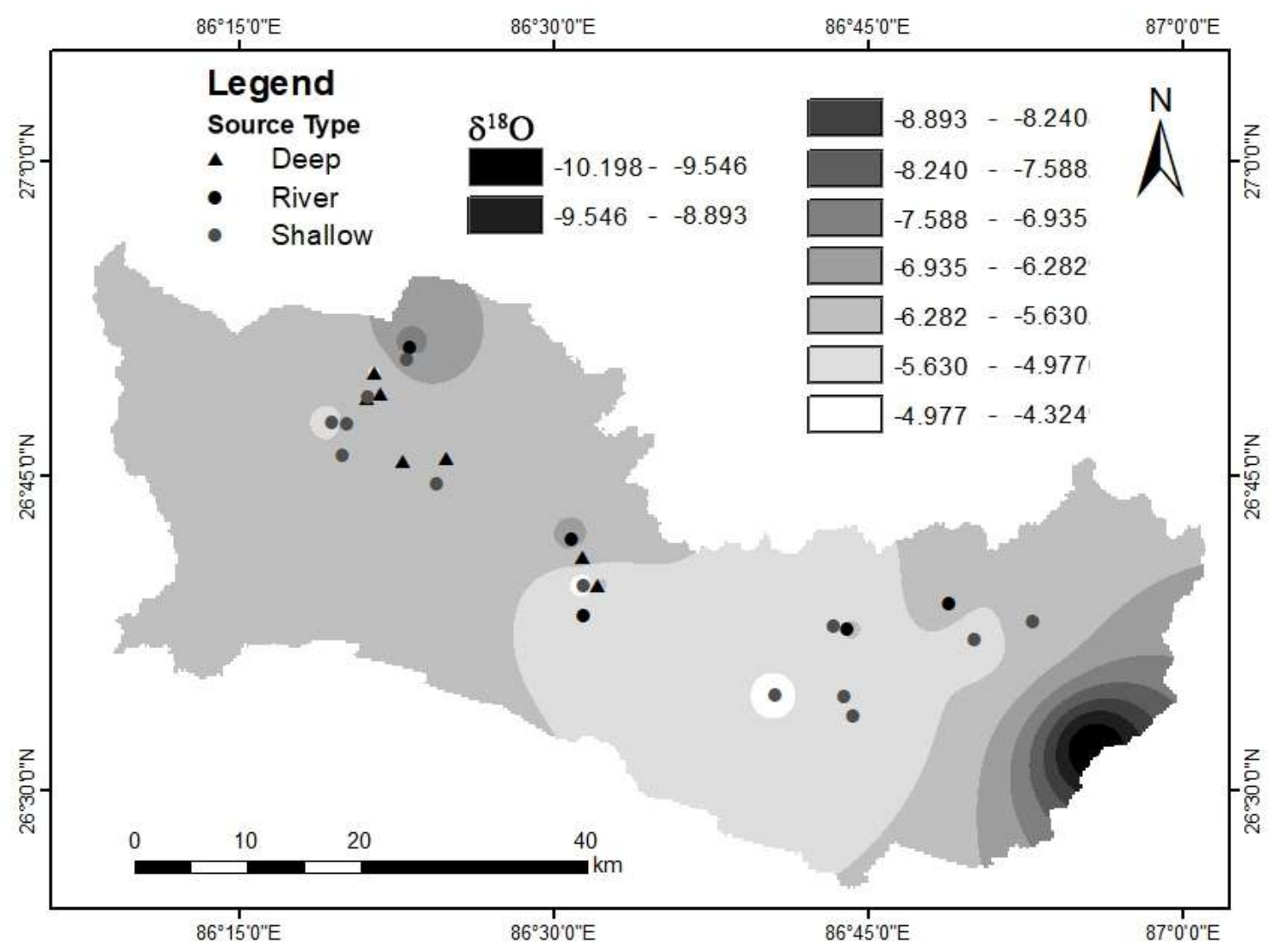

Fig. 10: Spatial distribution of $\delta 180$

water. From the isotopic evaluation, the $\delta^{18} \mathrm{O}$ composition of the water of the Koshi River is found to be the lightest one and the that at Haripur (Sigw15) and Shambhunath (Sigw20) were the heaviest. Based on the plot of $\delta^{18} \mathrm{O}$ vs $\delta^{2} \mathrm{H}$, the shallow tube well at Asanpur (Sigw5) and deep tube well at Jamdaha (Sigw4) might be recharged from the Kharak Khola (Sigw22). Similarly, deep tube well at Lalpur (Sigw3) and Kusaha (Sigw14), shallow tube well at Asanpur (Sigw5), Tudkiya (Sigw13) and Raghunathpur (Sigw18), Mahuli Khola (Sigw25) and Khado Khola (Sigw24) are interconnected. The deep tube well at Tudkiya (Sigw2), Dhangadhi (Sigw8) and Phulkakatti (Sigw9) might have interconnection with the shallow tube well at Khoriya (Sigw1) and Golamukhsar (Sigw12). But the lithological data shows different result as the representative lithologs were taken to the observed well. Hence forth the lithological data of the observed well could provide direct insight to the obtained result.

\section{REFERENCES}

Dhital, M. R., 2016, Geology of The Nepal Himalaya. Springer International Pu., pp. 498.

GRDP, 1994, Reassessment of the groundwater development strategy for irrigation in the Terai. Groundwater, HMG, Department of Irrigation, Groundwater Resources Development Project, v.3, 227p.
Mook, W. G., Rozanski, K. and Froelich, K., 2001, Environmental isotopes in the hydrological cycle: Principles and applications. Paris: UNESCO.

Nayak, P.C., Satyaji Rao, Y.R. and Sudheer, K.P., 2006, Groundwater level forecasting in a shallow aquifer using artificial neural network approach. Water Resour. Manage. v.20, pp. 77-90.

Pathak, D. and Rao, G.K., 1998, Groundwater recharge to the confined aquifer system in the Terai plain of Nawalparasi district, western Nepal: a hydrochemical approach, J. Nepal Geol. Soc., pp. 37-44.

Pinder, G. F., and Celia, M. A., 2006,ÊSubsurface hydrology. Hoboken: Wiley. 400p.

Pokhrel, D., Bhandari, B.S., and Viraraghavan, 2009, Arsenic contamination of groundwater in the Terai region of Nepal: An overview of health concerns and treatment options. Environ. Int., v.35, pp. 157-161.

Terwey, J.L., 1984, Isotopes in Groundwater Hydrology. Proceedings of the Harare Symposium: Challenges in African Hydrology and Water Resources, IAHS, Netherlands, pp. 155-160.

USGS, 2018, Natural processes of ground-water and surfacewater interaction. 